\title{
Implementasi Data Mining Menggunakan Asosiasi Dengan Algoritma Apriori Untuk Mendapatkan Pola Rekomendasi Belanja Produk Pada Toko Avis Mobile
}

\author{
Kamil Erwansyah, Beni Andika, Rudi Gunawan \\ Program Studi Sistem Informasi, STMIK Triguna Dharma
}

\begin{abstract}
Abstrak
Persaingan pasar yang terjadi dilingkungan masyarakat saat ini sangat tinggi. Melihat saat ini cukup banyak toko - toko yang mendirikan tokonya hanya berjarak tidak jauh dari toko sebelumnya. Hal ini akan memunculkan para pelaku usaha saling berebut konsumen dan bahkan menyebabkan persaingan yang tidak sehat, sehingga berdampak pada penjualan toko tersebut. Dengan demikian diperlukan strategi untuk meningkatkan penjualan pada toko, sehingga dapat meningkatkan penjualan pada toko tersebut.

Salah satu strategi untuk meningkatkan penjualan yaitu dengan pola rekomendasi belanja produk, dimana rekap data penjualan pada suatu toko diolah dengan menggunakan konsep data mining sehingga dapat memudahkan dalam menyelesaikan masalah yang terjadi pada toko Avis Mobile. Dengan metode asosiasi yang mampu mengenali kelakuan dari kejadian - kejadian khusus dengan tujuan untuk menemukan aturan atau pola yang ada didalam data.

Oleh sebab itu, algoritma apriori dapat merekomendasikan belanja produk untuk kedepannya berdasarkan data penjualan sebelumnya. Hasil dari penelitian ini dapat merekomendasikan belanja produk, sehingga dapat membantu toko tersebut.
\end{abstract}

Kata kunci : Data Mining, Metode Asosiasi, Algoritma Apriori, Rekomendasi Belanja Produk

\section{PENDAHULUAN}

Toko Avis Mobile merupakan sebuah toko yang menjual smartphone, kartu paket dan berbagai aksesoris lainnya seperti case handphone, power bank, dan lain - lain, berdiri sejak 31 November 2010, oleh pemilik toko Avis Mobile yaitu bapak Naito Wijaya.

Avis Mobile beralamat di jalan sutrisno no.282b dimana dijalan sutrisno cukup banyak toko - toko yang menjual produk yang hampir sama persis dengan yang dimiliki oleh toko Avis Mobile. Dengan produk yang hampir sama, maka perlu strategi untuk meningkatkan penjualan pada toko Avis Mobile. Salah satu strategi untuk meningkatkan penjualan adalah dengan adanya rekomendasi belanja produk, dimana data penjualan yang ada di Avis Mobile diolah agar dapat mengetahui produk apa yang bisa di rekomendasikan ke konsumen, bahkan pola rekomendasi belanja produk ini bisa menjadi sesuatu yang berbeda dari toko - toko lainnya.

Oleh sebab itu dibutuhkan metode asosiasi untuk mendapatkan pola rekomendasi belanja produk agar meningkatkan penjualan di toko Avis Mobile, melihat masyarakat saat ini masih ada yang belum mengetahui produk mana yang rekomendasi atau 
misalnya setelah membeli handphone kadang konsumen bisa saja lupa apa yang mau dibeli lagi, maka dari itu perlu pola rekomendasi agar karyawan dapat merekomendasikan setiap membeli handphone juga membeli kartu paket, atau case handphone atau yang lainnya.

\section{LANDASAN TEORITIS}

\subsection{Knowledge Discovery In Database (KKD)}

"Knowledge Discovery in Database (KDD) adalah proses untuk menentukan suatu informasi yang berguna dan aturan-aturan yang ada dalam data. Informasi ini terkandung dalam basis data yang berukuran besar sebelumnya tidak diketahuidan potensial bermanfaat. Data Mining merupakan salah satu langkah dari serangkaian proses iterative KDD”.

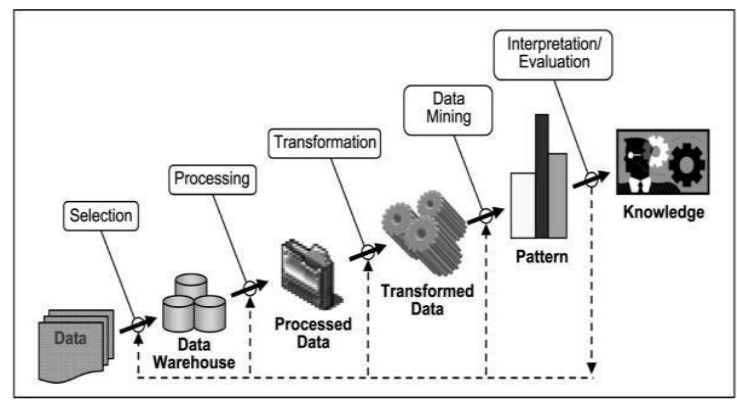

Gambar 1 Tahapan dalam KDD

Tahapan-tahapan proses KDD terdiri dari :

a. Data Selection

Pada proses ini dilakukan pemilihan himpunan data, menciptakan himpunan data target, atau memfokuskan pada sampel data dimana penemuan akan dilakukan. Hasil seleksi disimpan dalam suatu berkas yang terpisah dari basis data operasional.

b. Pre-Processing dan Cleaning Data

Pre-Processing dan Cleaning Data dilakukan dalam membuang data yang tidak konsisten dan noise, duplikasi data, memperbaiki kesalahan data, dan bisa diperkaya dengan data eksternal yang relevan.

c. Transformation

Proses ini menggabungkan data ke dalam yang lebih tepat untuk melakukan proses mining dengan cara melakukan peringkasan.

d. Data Mining

Proses Data Mining yaitu proses mencari pola atau informasi menarik dalam data terpilih dengan menggunakan teknik, metode atau algoritma tertentu sesuai dengan tujuan dari proses KDD secara keseluruhan.

e. Interpretation / Evaluasi

Proses untuk menerjemahkan pola - pola yang dihasilkan dari Data Mining.

Mengevaluasi apakah pola atau informasi yang ditemukan sesuai atau bertentangan dengan fakta atau hipotesa sebelumnya. Pengetahuan yang diperoleh dari pola - pola yang terbentuk dipresentasikan dalam bentuk visualisasi. 


\subsubsection{Data Mining}

'Data mining adalah proses yang mempekerjakan satu atau lebih teknik pembelajaran komputer (machine learning) untuk menganalisis dan mengekstraksi pengetahuan (knowledge) secara otomatis'. [3]

'Data mining didefinisikan sebagai sebuah proses untuk menentukan hubungan pola dan tren baru yang bermakna dengan menyaring, menggunakan teknik pengenalan pola seperti teknik statistik dan matematika'. [4]. 'Data mining adalah suatu proses menemukan hubungan yang berarti, pola dan kecenderungan dengan memeriksa dalam sekumpulan besar data yang tersimpan dalam penyimpanan dengan menggunakan teknik pengenalan pola seperti teknik statistic dan matematika'. [5] 'Hasil dari data mining bisa digunakan untuk membantu pengambilan keputusan kedepannya'.

\subsubsection{Konsep Data Mining}

Konsep data mining merupakan upaya dalam mengenali informasi yang tersembunyi didalam kumpulan data yang berjumlah besar. Data mining bukanlah suatu bidang ilmu yang baru, data mining muncul sekitar tahun 1990, disebabkan terjadinya penumpukkan data maka diperlukan data mining untuk menganalisis, mengestimasi dan mengelompokkan data tersebut.

Data mining sangat dibutuhkan terutama dalam mengelola data yang sangat besar untuk memudahkan aktivitas suatu transaksi Alasan mengapa data mining sangat menarik perhatian industri informasi bahkan sampai ke toko - toko dalam beberapa tahun sebelumnya karena data mining melakukan kegiatan ekstrasi atau lebih dikenal menambang pengetahuan dari data yang berjumlah besar, kemudian informasi ini yang nantinya sangat berguna untuk pengembangan.

\subsubsection{Teknik Data Mining}

Berikut adalah teknik yang akan digunakan di dalam data mining yaitu sebagai berikut:

1. Estimasi

Digunakan untuk melakukan estimasi terhadap sebuah data baru yang tidak memiliki keputusan berdasarkan histori data yang telah ada. Algoritma yang digunakan dalam pemecahan masalah yaitu algoritma regresi liniar berganda. Estimasi dapat digunakan seperti melakukan estimasi pembiayaan pada saat pembangunan sebuah mall baru pada kota berbeda.

2. Asosiasi

Digunakan untuk mengenali kelakuan dari kejadian - kerjadian khusus atau proses dimana hubungan asosiasi muncul pada setiap kejadian. Algoritma pemecahan masalah yang digunakan yaitu : algoritma apriori dan FP-Growht. Asosiasi dapat digunakan seperti pada bidang marketing sebuah toko handphone melakukan tata letak produk yang dijual berdasarkan produk mana yang paling sering dibeli konsumen.

3. Klasifikasi

Suatu teknik dengan melihat kelakuan dan atribut dari kelompok yang telah didefinisikan. Teknik ini dapat memberikan klasifikasi pada data baru dengan memanipulasi data yang ada telah diklasifikasi dan menggunakan hasilnya untuk memberikan sejumlah aturan. Algoritma pemecahan masalah yang digunakan yaitu : Algoritma C4.5, ID3 dan lain - lain. Klasifikasi dapat digunakan seperti kelayakan siswa untuk masuk kedalam kelas unggulan di sekolah tertentu. 


\section{Clustering}

Digunakan untuk menganalisis pengelompokkan yang berbeda terhadap data, mirip dengan klasifikasi, namun pengelompokkan belum didefinisikan sebelum dijalankannya tool data mining. Clustering membagi item menjadi kelompok kelompok berdasarkan yang ditemukan tool data mining. Contoh pengelompokan produk - produk berdasarkan yang paling laku, laku dan tidak laku. Algoritma yang bisa digunakan untuk pemecahan masalah yaitu K-Means, Fuzzy C-Means, dan lain lain.

5. Prediksi

Biasanya digunakan untuk memperkirakan suatu kejadian sebelum peristiwa tertentu terjadi. Contohnya pada bidang klimatologi dan geofisika, yaitu bagaimana badan meteorology dan geofisika (bmkg) memperkirakan bagaimana cuaca besok, apakah hujan, panas dan lain sebagainya. Algoritma yang sering digunakan salah satunya metode rough set.

\subsection{Algoritma Apriori}

Algoritma apriori termasuk jenis aturan asosiasi pada data mining. Aturan yang menyatakan asosiasi antara beberapa atribut sering disebut affinity analysis atau market basket analysis. Analisis asosiasi atau association rule mining adalah teknik data mining untuk menemukan aturan suatu kombinasi item. Salah satu tahap analisis asosiasi yang menarik perhatian banyak peneliti untuk menghasilkan algoritma yang efisien adalah analisis pola frequensi tinggi (frequent pattern mining). Penting tidaknya suatu asosiasi dapat diketahui dengan dua tolak ukur, yaitu : support dan confidence. Support (nilai penunjang) adalah persentasi kombinasi item tersebut dalam database, sedangkan confidence (nilai kepastian) adalah kuatnya suatu hubungan antar-item di dalam aturan asosiasi. (Pane, 2013 : 26).

Untuk menghitung nilai support pada sebuah item diperoleh dengan menggunakan rumus :

$$
\text { Support }(\mathrm{A})=\frac{\text { jumlah transaksi mengandung A }}{\text { total transaksi }} \times 100 \%
$$

Sedangkan untuk menghitung nilai support pada 2 (dua) item diperoleh dengan menggunakan rumus : Support $(\mathrm{A}, \mathrm{B})=\mathrm{P}(\mathrm{A} \cap \mathrm{B})$

Sementara untuk menghitung nilai confidence dapat diperoleh dengan menggunakan rumus :

$$
\text { Confidence }=\frac{\Sigma \text { transaksi mengandung A dan B }}{\Sigma \text { transaksi mengandung A }} \times 100 \%
$$

Untuk menentukan aturan asosiasi yang akan dipilih maka harus diurutkan berdasarkan support $\mathrm{x}$ confidence, dimana aturan diambil sebanyak $\mathrm{n}$ aturan yang memiliki hasil terbesar.

\section{ANALISA DAN HASIL}

Untuk mendapatkan pola rekomendasi belanja produk diperlukan data penjualan minimal 3 bulan yang kemudian data tersebut dipilih berdasarkan lebih dari 2 produk. Data penjualan yang akan diolah dengan algoritma apriori diambil dari toko Avis Mobile selama 3 bulan yaitu pada bulan Oktober, November dan Desember. Berikut 
data produk dan data transaksi yang didapatkam dari data penjualan pada toko Avis Mobile.

Tabel 1 Daftar Nama Produk

\begin{tabular}{|c|l|l|}
\hline No & \multicolumn{1}{|c|}{ Nama Produk } & \multicolumn{1}{c|}{ Jenis } \\
\hline 1 & Samsung & Handphone \\
\hline 2 & Xiaomi & Handphone \\
\hline 3 & Vivo & Handphone \\
\hline 4 & Oppo & Handphone \\
\hline 5 & Advan & Handphone \\
\hline 6 & Evercoss & Handphone \\
\hline 7 & Kartu Paket & Kuota Internet \\
\hline 8 & Kartu Perdana & Kartu SIM \\
\hline 9 & Soft Case & Aksesoris \\
\hline 10 & Anti Gores & Aksesoris \\
\hline 11 & Tongsis & Aksesoris \\
\hline 12 & OTG & Aksesoris \\
\hline 13 & Earphone & Aksesoris \\
\hline 14 & Iring & Aksesoris \\
\hline 15 & Power Bank & Aksesoris \\
\hline 16 & Waterproof & Aksesoris \\
\hline 17 & Gurita & Aksesoris \\
\hline 18 & Memori & Penyimpanan \\
\hline 19 & Flashdisk & Penyimpanan \\
\hline
\end{tabular}

Tabel 2 Data Transaksi Produk

\begin{tabular}{|c|c|l|}
\hline No & $\begin{array}{c}\text { Tanggal } \\
\text { Transaksi }\end{array}$ & \multicolumn{1}{|c|}{ Transaksi } \\
\hline 1 & $1 / 10 / 2018$ & $\begin{array}{l}\text { Xiaomi, Anti Gores, Soft Case, Gurita, Earphone, Kartu } \\
\text { Paket, Memori }\end{array}$ \\
\hline 2 & $2 / 10 / 2018$ & $\begin{array}{l}\text { Xiaomi, Anti Gores, Soft Case, Oppo, Memori, Advan, } \\
\text { Iring }\end{array}$ \\
\hline 3 & $3 / 10 / 2018$ & $\begin{array}{l}\text { Samsung, Evercoss, Soft Case, Waterproof, Power Bank, } \\
\text { Kartu Paket }\end{array}$ \\
\hline 4 & $6 / 10 / 2018$ & Xiaomi, Memori, Anti Gores, Kartu Perdana, Kartu Paket \\
\hline 5 & $8 / 10 / 2018$ & Flashdisk, Soft Case, Gurita, Earphone, Tongsis \\
\hline 6 & $9 / 10 / 2018$ & Oppo, Xiaomi, Kartu Perdana, Earphone \\
\hline 7 & $10 / 10 / 2018$ & Evercoss, Xiaomi, Anti Gores, Memori, Power Bank \\
\hline 8 & $15 / 10 / 2018$ & Oppo, OTG, Flashdisk, Kartu Paket \\
\hline 9 & $20 / 10 / 2018$ & $\begin{array}{l}\text { Oppo, Advan, Soft Case, Kartu Paket, Anti Gores, } \\
\text { Waterproof, Earphone }\end{array}$ \\
\hline 10 & $20 / 10 / 2018$ & $\begin{array}{l}\text { Xiaomi, Anti Gores, Samsung, Soft Case, Power Bank, } \\
\text { Gurita, Tongsis }\end{array}$ \\
\hline 11 & $28 / 10 / 2018$ & Vivo, Earphone, Anti Gores, Kartu Perdana \\
\hline 12 & $31 / 10 / 2018$ & Vivo, Soft Case, Iring, OTG, Flashdisk \\
\hline 13 & $4 / 11 / 2018$ & Vivo, Kartu Perdana, Earphone, Evercoss, Tongsis, Memori \\
\hline
\end{tabular}




\begin{tabular}{|c|c|l|}
14 & $10 / 11 / 2018$ & $\begin{array}{l}\text { Vivo, Xiaomi, Earphone, Waterproof, Kartu Paket, Kartu } \\
\text { Perdana }\end{array}$ \\
\hline 15 & $18 / 11 / 2018$ & $\begin{array}{l}\text { Xiaomi, Soft Case, Anti Gores, Tongsis, Gurita, Iring, Kartu } \\
\text { Perdana }\end{array}$ \\
\hline 16 & $22 / 11 / 2018$ & Samsung, Evercoss, Memori, Power Bank \\
\hline 17 & $25 / 11 / 2018$ & $\begin{array}{l}\text { Oppo, Xiaomi, Soft Case, Anti Gores, Earphone, Kartu } \\
\text { Paket }\end{array}$ \\
\hline 18 & $30 / 11 / 2018$ & $\begin{array}{l}\text { Oppo, Anti Gores, Kartu Paket, OTG, Samsung, Kartu } \\
\text { Perdana, Memori }\end{array}$ \\
\hline 19 & $1 / 12 / 2018$ & Vivo, Oppo, Xiaomi, Earphone, Kartu Paket, Waterproof \\
\hline 20 & $2 / 12 / 2018$ & Vivo, Advan, Oppo, Earphone, OTG, Flashdisk \\
\hline 21 & $5 / 12 / 2018$ & $\begin{array}{l}\text { Xiaomi, Oppo, Anti Gores, Soft Case, Vivo, Kartu Paket, } \\
\text { Earphone, Iring }\end{array}$ \\
\hline 22 & $7 / 12 / 2018$ & Oppo, OTG, Soft Case, Iring, Waterproof \\
\hline 23 & $10 / 12 / 2018$ & $\begin{array}{l}\text { Oppo, Kartu Paket, Soft Case, Earphone, Evercoss, Iring, } \\
\text { Memori }\end{array}$ \\
\hline 24 & $14 / 12 / 2018$ & Oppo, Anti Gores, Iring, OTG, Flashdisk, Soft Case \\
\hline 25 & $22 / 12 / 2018$ & Samsung, Xiaomi, Advan, Kartu Perdana, Anti Gores \\
\hline 26 & $23 / 12 / 2018$ & $\begin{array}{l}\text { Xiaomi, Samsung, Soft Case, Gurita, Vivo, Oppo, Kartu } \\
\text { Paket, Anti Gores, Waterproof, Power Bank, Iring, Tongsis }\end{array}$ \\
\hline 27 & $24 / 12 / 2018$ & Vivo, Samsung, Advan, Anti Gores, Power Bank \\
\hline 28 & $29 / 12 / 2018$ & $\begin{array}{l}\text { Oppo, Xiaomi, Soft Case, Anti Gores, Earphone, Power } \\
\text { Bank, Tongsis, Gurita, Kartu Perdana, Kartu Paket, Memori }\end{array}$ \\
\hline
\end{tabular}

\subsection{Menentukkan Support 1 Itemset}

Dari data transkasi pada tabel 3.2, maka dapat dicari nilai support 1 itemset dengan rumus sebagai berikut :

$$
\text { Support }(A)=\frac{\text { jumlah transaksi mengandung A }}{\text { total transaksi }} \times 100 \%
$$

Sehingga dapat dicari nilai support 1 itemset pada tabel dibawah ini :

Tabel 3 Hasil Support 1 Itemset

\begin{tabular}{|c|c|c|c|}
\hline No & Itemset & $\begin{array}{c}\text { Frekuensi } \\
\text { Kemunculan }\end{array}$ & Support 1 Itemset \\
\hline 1 & Samsung & 7 & $\frac{7}{28} \times 100 \%=25,00 \%$ \\
\hline 2 & Xiaomi & 14 & $\frac{14}{28} \times 100 \%=50,00 \%$ \\
\hline 3 & Vivo & 9 & $\frac{9}{28} \times 100 \%=32,14 \%$ \\
\hline 4 & Oppo & 14 & $\frac{14}{28} \times 100 \%=50,00 \%$ \\
\hline 5 & Advan & 5 & $\frac{5}{28} \times 100 \%=17,86 \%$ \\
\hline 6 & Evercoss & 5 & $\frac{5}{28} \times 100 \%=17,86 \%$ \\
\hline 7 & Kartu Paket & 13 & $\frac{13}{28} \times 100 \%=46,43 \%$ \\
\hline 8 & Kartu Perdana & 9 & $\frac{9}{28} \times 100 \%=32,14 \%$ \\
\hline
\end{tabular}




\begin{tabular}{|c|c|c|c|}
9 & Soft Case & 15 & $\frac{15}{28} \times 100 \%=53,57 \%$ \\
\hline 10 & Anti Gores & 16 & $\frac{16}{28} \times 100 \%=57,14 \%$ \\
\hline 11 & Tongsis & 6 & $\frac{6}{28} \times 100 \%=21,43 \%$ \\
\hline 12 & OTG & 6 & $\frac{6}{28} \times 100 \%=21,43 \%$ \\
\hline 13 & Earphone & 13 & $\frac{13}{28} \times 100 \%=46,43 \%$ \\
\hline 14 & Iring & 8 & $\frac{8}{28} \times 100 \%=28,57 \%$ \\
\hline 15 & Power Bank & 7 & $\frac{7}{28} \times 100 \%=25,00 \%$ \\
\hline 16 & Waterproof & 6 & $\frac{6}{28} \times 100 \%=21,43 \%$ \\
\hline 17 & Gurita & 6 & $\frac{6}{28} \times 100 \%=21,43 \%$ \\
\hline 18 & Memori & 9 & $\frac{9}{28} \times 100 \%=32,14 \%$ \\
\hline 19 & Flashdisk & 5 & $\frac{5}{28} \times 100 \%=17,86 \%$ \\
\hline
\end{tabular}

Dengan nilai support yang didapat, maka ditentukan minimum support sebesar $25 \%$, kemudian eliminasi nilai support 1 itemset yang tidak memenuhi ketentuan minimum support yaitu sebagai berikut :

Tabel 4 Hasil Minimum Support 1 Itemset

\begin{tabular}{|c|c|c|c|}
\hline No & Itemset & $\begin{array}{c}\text { Frekuensi } \\
\text { Kemunculan }\end{array}$ & $\begin{array}{c}\text { Support 1 } \\
\text { Itemset }\end{array}$ \\
\hline 1 & Samsung & 7 & $25,00 \%$ \\
\hline 2 & Xiaomi & 14 & $50,00 \%$ \\
\hline 3 & Vivo & 9 & $32,14 \%$ \\
\hline 4 & Oppo & 14 & $50,00 \%$ \\
\hline 5 & Kartu Paket & 13 & $46,43 \%$ \\
\hline 6 & Kartu Perdana & 9 & $32,14 \%$ \\
\hline 7 & Soft Case & 15 & $53,57 \%$ \\
\hline 8 & Anti Gores & 16 & $57,14 \%$ \\
\hline 9 & Earphone & 13 & $46,43 \%$ \\
\hline 10 & Iring & 8 & $28,57 \%$ \\
\hline 11 & Power Bank & 7 & $25,00 \%$ \\
\hline 12 & Memori & 9 & $32,14 \%$ \\
\hline
\end{tabular}

\subsection{Menentukkan Support 2 Itemset}

Dari data transkasi pada tabel 3.2 dan hasil minimum support 1 itemset pada tabel 3.3, maka dapat dicari nilai support 2 itemset dengan rumus sebagai berikut :

$$
\text { Support }=\frac{\sum \text { transaksi mengandung A dan B }}{\text { total transaksi }} \times 100 \%
$$

Sehingga dapat dicari nilai support 2 itemset pada tabel dibawah ini : 
Tabel 5 Hasil Support 2 Itemset

\begin{tabular}{|c|c|c|c|}
\hline No & Itemset & $\begin{array}{c}\text { Frekuensi } \\
\text { Kemunculan }\end{array}$ & Support 2 Itemset \\
\hline 1 & Samsung, Xiaomi & 3 & $\frac{3}{28} \times 100 \%=10,71 \%$ \\
\hline 2 & Samsung, Vivo & 2 & $\frac{2}{28} \times 100 \%=7,14 \%$ \\
\hline 3 & Samsung, Oppo & 2 & $\frac{2}{28} \times 100 \%=7,14 \%$ \\
\hline 4 & Samsung, Kartu Paket & 3 & $\frac{3}{28} \times 100 \%=10,71 \%$ \\
\hline 5 & $\begin{array}{l}\text { Samsung, Kartu } \\
\text { Perdana }\end{array}$ & 2 & $\frac{2}{28} \times 100 \%=7,14 \%$ \\
\hline 6 & Samsung, Soft Case & 3 & $\frac{3}{28} \times 100 \%=10,71 \%$ \\
\hline 7 & Samsung, Anti Gores & 5 & $\frac{5}{28} \times 100 \%=17,86 \%$ \\
\hline 8 & Samsung, Earphone & 0 & $\frac{0}{28} \times 100 \%=0,00 \%$ \\
\hline 9 & Samsung, Iring & 1 & $\frac{1}{28} \times 100 \%=3,57 \%$ \\
\hline 10 & Samsung, Power Bank & 5 & $\frac{5}{28} \times 100 \%=17,86 \%$ \\
\hline 11 & Samsung, Memori & 2 & $\frac{2}{28} \times 100 \%=7,14 \%$ \\
\hline 12 & Xiaomi, Vivo & 4 & $\frac{4}{28} \times 100 \%=14,29 \%$ \\
\hline 13 & Xiaomi, Oppo & 7 & $\frac{7}{28} \times 100 \%=25,00 \%$ \\
\hline 14 & Xiaomi, Kartu Paket & 8 & $\frac{8}{28} \times 100 \%=28,57 \%$ \\
\hline 15 & Xiaomi, Kartu Perdana & 6 & $\frac{6}{28} \times 100 \%=21,43 \%$ \\
\hline 16 & Xiaomi, Soft Case & 8 & $\frac{8}{28} \times 100 \%=28,57 \%$ \\
\hline 17 & Xiaomi, Anti Gores & 11 & $\frac{11}{28} \times 100 \%=39,29 \%$ \\
\hline 18 & Xiaomi, Earphone & 7 & $\frac{7}{28} \times 100 \%=25,00 \%$ \\
\hline 19 & Xiaomi, Iring & 4 & $\frac{4}{28} \times 100 \%=14,29 \%$ \\
\hline 20 & Xiaomi, Power Bank & 4 & $\frac{4}{28} \times 100 \%=14,29 \%$ \\
\hline 21 & Xiaomi, Memori & 5 & $\frac{5}{28} \times 100 \%=17,86 \%$ \\
\hline 22 & Vivo, Oppo & 4 & $\frac{4}{28} \times 100 \%=14,29 \%$ \\
\hline 23 & Vivo, Kartu Paket & 4 & $\frac{4}{28} \times 100 \%=14,29 \%$ \\
\hline 24 & Vivo, Kartu Perdana & 3 & $\frac{3}{28} \times 100 \%=10,71 \%$ \\
\hline 25 & Vivo, Soft Case & 3 & $\frac{3}{28} \times 100 \%=10,71 \%$ \\
\hline 26 & Vivo, Anti Gores & 4 & $\frac{4}{28} \times 100 \%=14,29 \%$ \\
\hline 27 & Vivo, Earphone & 6 & $\frac{6}{28} \times 100 \%=21,43 \%$ \\
\hline 28 & Vivo, Iring & 3 & $\frac{3}{28} \times 100 \%=10,71 \%$ \\
\hline 29 & Vivo, Power Bank & 2 & $\frac{2}{28} \times 100 \%=7,14 \%$ \\
\hline 30 & Vivo, Memori & 1 & $\frac{1}{28} \times 100 \%=3,57 \%$ \\
\hline 31 & Oppo, Kartu Paket & 9 & $\frac{9}{28} \times 100 \%=32,14 \%$ \\
\hline 32 & Oppo, Kartu Perdana & 3 & $\frac{3}{28} \times 100 \%=10,71 \%$ \\
\hline
\end{tabular}




\begin{tabular}{|c|c|c|c|}
\hline 33 & Oppo, Soft Case & 9 & $\frac{9}{28} \times 100 \%=32,14 \%$ \\
\hline 34 & Oppo, Anti Gores & 8 & $\frac{8}{28} \times 100 \%=28,57 \%$ \\
\hline 35 & Oppo, Earphone & 8 & $\frac{8}{28} \times 100 \%=28,57 \%$ \\
\hline 36 & Oppo, Iring & 6 & $\frac{6}{28} \times 100 \%=21,43 \%$ \\
\hline 37 & Oppo, Power Bank & 2 & $\frac{2}{28} \times 100 \%=7,14 \%$ \\
\hline 38 & Oppo, Memori & 4 & $\frac{4}{28} \times 100 \%=14,29 \%$ \\
\hline 39 & $\begin{array}{c}\text { Kartu Paket, Kartu } \\
\text { Perdana } \\
\end{array}$ & 4 & $\frac{4}{28} \times 100 \%=14,29 \%$ \\
\hline 40 & Kartu Paket, Soft Case & 8 & $\frac{8}{28} \times 100 \%=28,57 \%$ \\
\hline 41 & $\begin{array}{l}\text { Kartu Paket, Anti } \\
\text { Gores }\end{array}$ & 8 & $\frac{8}{28} \times 100 \%=28,57 \%$ \\
\hline 42 & Kartu Paket, Earphone & 8 & $\frac{8}{28} \times 100 \%=28,57 \%$ \\
\hline 43 & Kartu Paket, Iring & 3 & $\frac{3}{28} \times 100 \%=10,71 \%$ \\
\hline 44 & $\begin{array}{c}\text { Kartu Paket, Power } \\
\text { Bank }\end{array}$ & 3 & $\frac{3}{28} \times 100 \%=10,71 \%$ \\
\hline 45 & Kartu Paket, Memori & 5 & $\frac{5}{28} \times 100 \%=17,86 \%$ \\
\hline 46 & $\begin{array}{c}\text { Kartu Perdana, Soft } \\
\text { Case }\end{array}$ & 2 & $\frac{2}{28} \times 100 \%=7,14 \%$ \\
\hline 47 & $\begin{array}{l}\text { Kartu Perdana, Anti } \\
\text { Gores }\end{array}$ & 6 & $\frac{6}{28} \times 100 \%=21,43 \%$ \\
\hline 48 & $\begin{array}{c}\text { Kartu Perdana, } \\
\text { Earphone }\end{array}$ & 5 & $\frac{5}{28} \times 100 \%=17,86 \%$ \\
\hline 49 & Kartu Perdana, Iring & 1 & $\frac{1}{28} \times 100 \%=3,57 \%$ \\
\hline 50 & $\begin{array}{c}\text { Kartu Perdana, Power } \\
\text { Bank }\end{array}$ & 1 & $\frac{1}{28} \times 100 \%=3,57 \%$ \\
\hline 51 & Kartu Perdana, Memori & 4 & $\frac{4}{28} \times 100 \%=14,29 \%$ \\
\hline 52 & Soft Case, Anti Gores & 10 & $\frac{10}{28} \times 100 \%=35,71 \%$ \\
\hline 53 & Soft Case, Earphone & 7 & $\frac{7}{28} \times 100 \%=25,00 \%$ \\
\hline 54 & Soft Case, Iring & 8 & $\frac{8}{28} \times 100 \%=28,57 \%$ \\
\hline 55 & Soft Case, Power Bank & 4 & $\frac{4}{28} \times 100 \%=14,29 \%$ \\
\hline 56 & Soft Case, Memori & 4 & $\frac{4}{28} \times 100 \%=14,29 \%$ \\
\hline 57 & Anti Gores, Earphone & 6 & $\frac{6}{28} \times 100 \%=21,43 \%$ \\
\hline 58 & Anti Gores, Iring & 5 & $\frac{5}{28} \times 100 \%=17,86 \%$ \\
\hline 59 & $\begin{array}{c}\text { Anti Gores, Power } \\
\text { Bank }\end{array}$ & 5 & $\frac{5}{28} \times 100 \%=17,86 \%$ \\
\hline 60 & Anti Gores, Memori & 6 & $\frac{6}{28} \times 100 \%=21,43 \%$ \\
\hline 61 & Earphone, Iring & 2 & $\frac{2}{28} \times 100 \%=7,14 \%$ \\
\hline 62 & $\begin{array}{c}\text { Earphone, Power } \\
\text { Bank }\end{array}$ & 1 & $\frac{1}{28} \times 100 \%=3,57 \%$ \\
\hline 63 & Earphone, Memori & 4 & $\frac{4}{28} \times 100 \%=14,29 \%$ \\
\hline
\end{tabular}




\begin{tabular}{|c|c|c|c|}
64 & Iring, Power Bank & 1 & $\frac{1}{28} \times 100 \%=3,57 \%$ \\
\hline 65 & Iring, Memori & 2 & $\frac{2}{28} \times 100 \%=7,14 \%$ \\
\hline 66 & Power Bank, Memori & 3 & $\frac{3}{28} \times 100 \%=10,71 \%$ \\
\hline
\end{tabular}

Dengan nilai support 2 itemset yang didapat, kemudian eliminasi nilai support yang tidak memenuhi ketentuan minimum support yaitu sebagai berikut :

Tabel 6 Hasil Minimum Support 2 Itemset

\begin{tabular}{|c|c|c|c|}
\hline NO & Itemset & $\begin{array}{c}\text { Frekuensi } \\
\text { Kemunculan }\end{array}$ & $\begin{array}{c}\text { Support 2 } \\
\text { Itemset }\end{array}$ \\
\hline 1 & Xiaomi, Oppo & 7 & $25,00 \%$ \\
\hline 2 & Xiaomi, Kartu Paket & 8 & $28,57 \%$ \\
\hline 3 & Xiaomi, Soft Case & 8 & $28,57 \%$ \\
\hline 4 & Xiaomi, Anti Gores & 11 & $39,29 \%$ \\
\hline 5 & Xiaomi, Earphone & 7 & $25,00 \%$ \\
\hline 6 & Oppo, Kartu Paket & 9 & $32,14 \%$ \\
\hline 7 & Oppo, Soft Case & 9 & $32,14 \%$ \\
\hline 8 & Oppo, Anti Gores & 8 & $28,57 \%$ \\
\hline 9 & Oppo, Earphone & 8 & $28,57 \%$ \\
\hline 10 & Kartu Paket, Soft Case & 8 & $28,57 \%$ \\
\hline 11 & Kartu Paket, Anti Gores & 8 & $28,57 \%$ \\
\hline 12 & Kartu Paket, Earphone & 8 & $28,57 \%$ \\
\hline 13 & Soft Case, Anti Gores & 10 & $35,71 \%$ \\
\hline 14 & Soft Case, Earphone & 7 & $25,00 \%$ \\
\hline 15 & Soft Case, Iring & 8 & $28,57 \%$ \\
\hline \multicolumn{3}{|c|}{} \\
\hline
\end{tabular}

\subsection{Menentukkan Confidence}

Selanjutnya akan dihitung nilai confidence dengan aturan minimum confidence $=$ 60\%. Nilai confidence ditentukan dari setiap kombinasi yang terdapat pada tabel 3.6 berdasarkan rumus :

$$
\text { Confidence }=\frac{\sum \text { Transaksi mengandung A dan B }}{\sum \text { Transaksi mengandung A }} \times 100 \%
$$

Sehingga dapat dicari nilai confidence seperti pada tabel dibawah ini :

Tabel 7 Hasil Confidence

\begin{tabular}{|c|c|c|c|c|}
\hline No & Itemset & $\begin{array}{c}\text { Frekuensi } \\
\text { Kemunculan } \\
\text { A }\end{array}$ & $\begin{array}{c}\text { Frekuensi } \\
\text { Kemunculan } \\
\text { A } \cap \text { B }\end{array}$ & Confidence \\
\hline 1 & Xiaomi, Oppo & 14 & 7 & $\frac{7}{14} \times 100 \%=50,00 \%$ \\
\hline 2 & Oppo, Xiaomi & 14 & 7 & $\frac{7}{14} \times 100 \%=50,00 \%$ \\
\hline 3 & $\begin{array}{c}\text { Xiaomi, Kartu } \\
\text { Paket }\end{array}$ & 14 & 8 & $\frac{8}{14} \times 100 \%=57,14 \%$ \\
\hline 4 & $\begin{array}{c}\text { Kartu Paket, } \\
\text { Xiaomi }\end{array}$ & 13 & 8 & $\frac{8}{13} \times 100 \%=61,54 \%$ \\
\hline
\end{tabular}


Tabel 7 Hasil Confidence (Lanjutan)

\begin{tabular}{|c|c|c|c|c|}
\hline No & Itemset & $\begin{array}{c}\text { Frekuensi } \\
\text { Kemunculan } \\
\text { A }\end{array}$ & $\begin{array}{c}\text { Frekuensi } \\
\text { Kemunculan } \\
\mathbf{A} \cap \mathbf{B}\end{array}$ & Confidence \\
\hline 5 & $\begin{array}{c}\text { Xiaomi, Soft } \\
\text { Case }\end{array}$ & 14 & 8 & $\frac{8}{14} \times 100 \%=57,14 \%$ \\
\hline 6 & $\begin{array}{l}\text { Soft Case, } \\
\text { Xiaomi }\end{array}$ & 15 & 8 & $\frac{8}{15} \times 100 \%=53,33 \%$ \\
\hline 7 & $\begin{array}{l}\text { Xiaomi, Anti } \\
\text { Gores }\end{array}$ & 14 & 11 & $\frac{11}{14} \times 100 \%=78,57 \%$ \\
\hline 8 & $\begin{array}{l}\text { Anti Gores, } \\
\text { Xiaomi }\end{array}$ & 16 & 11 & $\frac{11}{16} \times 100 \%=68,75 \%$ \\
\hline 9 & $\begin{array}{l}\text { Xiaomi, } \\
\text { Earphone }\end{array}$ & 14 & 7 & $\frac{7}{14} \times 100 \%=50,00 \%$ \\
\hline 10 & $\begin{array}{l}\text { Earphone, } \\
\text { Xiaomi }\end{array}$ & 13 & 7 & $\frac{7}{13} \times 100 \%=53,85 \%$ \\
\hline 11 & $\begin{array}{l}\text { Oppo, Kartu } \\
\text { Paket }\end{array}$ & 14 & 9 & $\frac{9}{14} \times 100 \%=64,29 \%$ \\
\hline 12 & $\begin{array}{l}\text { Kartu Paket, } \\
\text { Oppo }\end{array}$ & 13 & 9 & $\frac{9}{13} \times 100 \%=69,23 \%$ \\
\hline 13 & $\begin{array}{l}\text { Oppo, Soft } \\
\text { Case }\end{array}$ & 14 & 9 & $\frac{9}{14} \times 100 \%=64,29 \%$ \\
\hline 14 & $\begin{array}{l}\text { Soft Case, } \\
\text { Oppo }\end{array}$ & 15 & 9 & $\frac{9}{15} \times 100 \%=60,00 \%$ \\
\hline 15 & $\begin{array}{l}\text { Oppo, Anti } \\
\text { Gores }\end{array}$ & 14 & 8 & $\frac{8}{14} \times 100 \%=57,14 \%$ \\
\hline 16 & $\begin{array}{l}\text { Anti Gores, } \\
\text { Oppo }\end{array}$ & 16 & 8 & $\frac{8}{16} \times 100 \%=50,00 \%$ \\
\hline 17 & $\begin{array}{c}\text { Oppo, } \\
\text { Earphone }\end{array}$ & 14 & 8 & $\frac{8}{14} \times 100 \%=57,14 \%$ \\
\hline 17 & $\begin{array}{c}\text { Oppo, } \\
\text { Earphone }\end{array}$ & 14 & 8 & $\frac{8}{14} \times 100 \%=57,14 \%$ \\
\hline 18 & $\begin{array}{l}\text { Earphone, } \\
\text { Oppo }\end{array}$ & 13 & 8 & $\frac{8}{13} \times 100 \%=61,54 \%$ \\
\hline 19 & $\begin{array}{l}\text { Kartu Paket, } \\
\text { Soft Case }\end{array}$ & 13 & 8 & $\frac{8}{13} \times 100 \%=61,54 \%$ \\
\hline 20 & $\begin{array}{c}\text { Soft Case, } \\
\text { Kartu Paket }\end{array}$ & 15 & 8 & $\frac{8}{15} \times 100 \%=53,33 \%$ \\
\hline 21 & $\begin{array}{l}\text { Kartu Paket, } \\
\text { Anti Gores }\end{array}$ & 13 & 8 & $\frac{8}{13} \times 100 \%=61,54 \%$ \\
\hline 22 & $\begin{array}{l}\text { Anti Gores, } \\
\text { Kartu Paket }\end{array}$ & 16 & 8 & $\frac{8}{16} \times 100 \%=50,00 \%$ \\
\hline 23 & $\begin{array}{l}\text { Kartu Paket, } \\
\text { Earphone }\end{array}$ & 13 & 8 & $\frac{8}{13} \times 100 \%=61,54 \%$ \\
\hline 24 & $\begin{array}{c}\text { Earphone, } \\
\text { Kartu Paket }\end{array}$ & 13 & 8 & $\frac{8}{13} \times 100 \%=61,54 \%$ \\
\hline 25 & Soft Case, & 15 & 10 & $\frac{10}{15} \times 100 \%=66,67 \%$ \\
\hline
\end{tabular}




\begin{tabular}{|c|c|c|c|c|}
\hline 26 & $\begin{array}{c}\text { Anti Gores } \\
\text { Anti Gores, } \\
\text { Soft Case }\end{array}$ & 16 & 10 & $\frac{10}{16} \times 100 \%=62,50 \%$ \\
\hline 27 & $\begin{array}{c}\text { Soft Case, } \\
\text { Earphone }\end{array}$ & 15 & 7 & $\frac{7}{15} \times 100 \%=46,67 \%$ \\
\hline 28 & $\begin{array}{c}\text { Earphone, } \\
\text { Soft Case }\end{array}$ & 13 & 7 & $\frac{7}{13} \times 100 \%=53,85 \%$ \\
\hline 29 & $\begin{array}{c}\text { Soft Case, } \\
\text { Iring }\end{array}$ & 15 & 8 & $\frac{8}{15} \times 100 \%=53,33 \%$ \\
\hline 30 & $\begin{array}{c}\text { Iring, Soft } \\
\text { Case }\end{array}$ & 8 & 8 & $\frac{8}{8} \times 100 \%=100,00 \%$ \\
\hline
\end{tabular}

Dengan nilai confidence yang didapat, kemudian eliminasi nilai confidence yang tidak memenuhi ketentuan minimum confidence yaitu sebagai berikut :

Tabel 8 Hasil Minimum Confidence

\begin{tabular}{|c|c|c|c|c|}
\hline No & Aturan & $\begin{array}{c}\text { Frekuensi } \\
\text { Kemunculan } \\
\text { A }\end{array}$ & $\begin{array}{c}\text { Frekuensi } \\
\text { Kemunculan } \\
\text { A } \cap \text { B }\end{array}$ & Confidence \\
\hline 1 & Kartu Paket, Xiaomi & 13 & 8 & $61,54 \%$ \\
\hline 2 & Xiaomi, Anti Gores & 14 & 11 & $78,57 \%$ \\
\hline 3 & Anti Gores, Xiaomi & 16 & 11 & $68,75 \%$ \\
\hline 4 & Oppo, Kartu Paket & 14 & 9 & $64,29 \%$ \\
\hline 5 & Kartu Paket, Oppo & 13 & 9 & $69,23 \%$ \\
\hline 6 & Oppo, Soft Case & 14 & 9 & $64,29 \%$ \\
\hline 7 & Soft Case, Oppo & 15 & 9 & $60,00 \%$ \\
\hline 8 & Earphone, Oppo & 13 & 8 & $61,54 \%$ \\
\hline 9 & Kartu Paket, Soft Case & 13 & 8 & $61,54 \%$ \\
\hline 10 & Kartu Paket, Anti Gores & 13 & 8 & $61,54 \%$ \\
\hline 11 & Kartu Paket, Earphone & 13 & 8 & $61,54 \%$ \\
\hline 12 & Earphone, Kartu Paket & 13 & 8 & $61,54 \%$ \\
\hline 13 & Soft Case, Anti Gores & 15 & 10 & $66,67 \%$ \\
\hline 14 & Anti Gores, Soft Case & 16 & 10 & $62,50 \%$ \\
\hline 15 & Iring, Soft Case & 8 & 8 & $100,00 \%$ \\
\hline
\end{tabular}

\subsection{Pembentukan Aturan Asosiasi}

Setelah mendapatkan nilai support dan confidence yang telah memenuhi pola kombinasi 2 itemset, dengan ketentuan minimum support $=25 \%$ dan minimum confidence $60 \%$ maka aturan asosiasi yang terbentuk adalah sebagai berikut :

Tabel 9 Aturan Asosiasi Yang Terbentuk

\begin{tabular}{|c|c|c|c|}
\hline No & Aturan & Support & Confidence \\
\hline 1 & Kartu Paket, Xiaomi & $28,57 \%$ & $61,54 \%$ \\
\hline 2 & Xiaomi, Anti Gores & $39,29 \%$ & $78,57 \%$ \\
\hline 3 & Anti Gores, Xiaomi & $39,29 \%$ & $68,75 \%$ \\
\hline 4 & Oppo, Kartu Paket & $32,14 \%$ & $64,29 \%$ \\
\hline
\end{tabular}




\begin{tabular}{|c|c|c|c|}
\hline 5 & Kartu Paket, Oppo & $32,14 \%$ & $69,23 \%$ \\
\hline 6 & Oppo, Soft Case & $32,14 \%$ & $64,29 \%$ \\
\hline 7 & Soft Case, Oppo & $32,14 \%$ & $60,00 \%$ \\
\hline 8 & Earphone, Oppo & $28,57 \%$ & $61,54 \%$ \\
\hline 9 & Kartu Paket, Soft Case & $28,57 \%$ & $61,54 \%$ \\
\hline 10 & Kartu Paket, Anti Gores & $28,57 \%$ & $61,54 \%$ \\
\hline 11 & Kartu Paket, Earphone & $28,57 \%$ & $61,54 \%$ \\
\hline 12 & Earphone, Kartu Paket & $28,57 \%$ & $61,54 \%$ \\
\hline 13 & Soft Case, Anti Gores & $35,71 \%$ & $66,67 \%$ \\
\hline 14 & Anti Gores, Soft Case & $35,71 \%$ & $62,50 \%$ \\
\hline 15 & Iring, Soft Case & $28,57 \%$ & $100,00 \%$ \\
\hline
\end{tabular}

\subsection{Hasil Rekomendasi}

Dari aturan asosiasi yang didapat maka dapat ditentukkan hasil rekomendasi yang akan dipergunakan oleh pihak toko :

Tabel 10 Hasil Rekomendasi

\begin{tabular}{|c|l|}
\hline No & \multicolumn{1}{|c|}{ Hasil Rekomendasi } \\
\hline 1 & $\begin{array}{l}\text { Jika konsumen membeli Kartu Paket, maka dapat direkomendasikan } \\
\text { Handphone Xiaomi kepada konsumen }\end{array}$ \\
\hline 2 & $\begin{array}{l}\text { Jika konsumen membeli Handphone Xiaomi, maka dapat } \\
\text { direkomendasikan Anti Gores kepada konsumen }\end{array}$ \\
\hline 3 & $\begin{array}{l}\text { Jika konsumen membeli Anti Gores, maka dapat direkomendasikan } \\
\text { Handphone Xiaomi kepada konsumen }\end{array}$ \\
\hline 4 & $\begin{array}{l}\text { Jika konsumen membeli Handphone Oppo, maka dapat } \\
\text { direkomendasikan Kartu Paket kepada konsumen }\end{array}$ \\
\hline 5 & $\begin{array}{l}\text { Jika konsumen membeli Kartu Paket, maka dapat direkomendasikan } \\
\text { Handphone Oppo kepada konsumen }\end{array}$ \\
\hline 6 & $\begin{array}{l}\text { Jika konsumen membeli Handphone Oppo, maka dapat } \\
\text { direkomendasikan Soft Case kepada konsumen }\end{array}$ \\
\hline 7 & $\begin{array}{l}\text { Jika konsumen membeli Soft Case, maka dapat direkomendasikan } \\
\text { Handphone Oppo kepada konsumen }\end{array}$ \\
\hline 8 & $\begin{array}{l}\text { Jika konsumen membeli Earphone, maka dapat direkomendasikan } \\
\text { Handphone Oppo kepada konsumen }\end{array}$ \\
\hline 9 & $\begin{array}{l}\text { Jika konsumen membeli Kartu Paket, maka dapat direkomendasikan } \\
\text { Soft Case kepada konsumen }\end{array}$ \\
\hline 10 & $\begin{array}{l}\text { Jika konsumen membeli Kartu Paket, maka dapat direkomendasikan } \\
\text { Anti Gores kepada konsumen }\end{array}$ \\
\hline 11 & $\begin{array}{l}\text { Jika konsumen membeli Kartu Paket, maka dapat direkomendasikan } \\
\text { Earphone kepada konsumen }\end{array}$ \\
\hline 12 & $\begin{array}{l}\text { Jika konsumen membeli Earphone, maka dapat direkomendasikan } \\
\text { Kartu Paket kepada konsumen }\end{array}$ \\
\hline 13 & $\begin{array}{l}\text { Jika konsumen membeli Soft Case, maka dapat direkomendasikan Anti } \\
\text { Gores kepada konsumen }\end{array}$ \\
\hline 14 & $\begin{array}{l}\text { Jika konsumen membeli Anti Gores, maka dapat direkomendasikan } \\
\text { Soft Case kepada konsumen }\end{array}$ \\
\hline 15 & $\begin{array}{l}\text { Jika konsumen membeli Iring, maka dapat direkomendasikan Soft Case } \\
\text { kepada konsumen }\end{array}$ \\
\hline
\end{tabular}




\section{KESIMPULAN}

Metode asosiasi dengan algoritma apriori diterapkan dengan cara melakukan perhitungan menggunakan algoritma apriori kemudian melakukan pembentukan aturan asosiasi sehingga didapat pola rekomendasi belanja produk pada toko Avis Mobile.

\section{DAFTAR PUSTAKA}

[1] Assiroj, P. (2016). Penerapan Data Mining Pada Data Transaksi Superstore Untuk Mengetahui Kemungkinan Pelanggan Membeli Product Category Dan Product Container Secara Bersamaan Dengan Teknik Asosiasi Menggunakan Algoritma Apriori. Jurnal Ilmu Komputer \& Teknologi Informasi, 1(1), 11-18.

[2] Fadlina. (2014). Data Mining Untuk Analisa Tingkat Kejahatan Jalan Dengan Algoritma Association Rule Metode Apriori. Majalah Ilmiah Informasi Dan Teknologi Ilmiah (INTI), III(1), 144-154.

[3] Ikhwan, A., Nofriansyah, D., \& Sriani. (2015). Penerapan Data Mining dengan Algoritma Fp-Growth untuk Mendukung Strategi Promosi Pendidikan ( Studi Kasus Kampus STMIK Triguna Dharma ). Jurnal Ilmiah SAINTIKOM Sains dan Komputer, 14(3). 211-226

[4] Maharani., Hasibuan, N. A., Silalahi, N., Nasution, S. D., Mesran., Suginam., et al. (2017). Implementasi Data Mining Untuk Pengaturan Layout Minimarket Dengan Menerapkan Association Rule. Jurnal Riset Komputer (JURIKOM), 4(4), 6-11.

[5] Madcoms. 2011. Pasti Bisa Belajar Sendiri Microsoft Access 2010. Yogyakarta : Andi.

[6] Munawaroh, S. (2006). Perancangan Sistem Informasi Persediaan Barang. Jurnal Teknologi Informasi DINAMIK, 10(2), 124-133.

[7] Nofriansyah, D., Erwansyah, K., \& Ramadhan, M., (2016). Penerapan Data Mining dengan Algoritma Naive Bayes Clasifier untuk Mengetahui Minat Beli Pelanggan terhadap Kartu Internet XL ( Studi Kasus di CV. Sumber Utama). Jurnal Ilmiah SAINTIKOM Sains dan Komputer, 15(2). 81-92.

[8] Pane, D. K. (2013). Implementasi Data Mining Pada Penjualan Produk Elektronik Dengan Algoritma Apriori ( Studi Kasus: Kreditplus ). Pelita Informatika Budi Darma, 4(3), 25-29.

[9] S, Rosa A., \& Shalahuddin, M. 2013. Rekayasa Perangkat Lunak Terstruktur dan Berorientasi Objek. Bandung : Informatika

[19] Sulindawati., Fathoni, M. (2011). Pengantar Analisa Perancangan “ Sistem “. Jurnal Saintikom, 9(2), 1-19.

[11] Syahra, Y. (2018). Penerapan Data Mining Dalam Pengelompokkan Data Nilai Siswa Untuk Penentuan Jurusan Siswa Pada SMA Tamora Menggunakan Algoritma K-Means Clustering, Jurnal Ilmiah SAINTIKOM Sains dan Komputer, 17(2). 228-233.

[12] Tampubolon, K., Saragih, H., Reza, B. (2013). Implementasi Data Mining Algoritma Apriori Pada Sistem Persediaan Alat-Alat Kesehatan. Majalalah Ilmiah Informasi dan Teknologi (INTI), I(1). 94-106. 